\title{
MYYTTINEN DISKURSSI JA MYTOLOGIAN SYMBOLINEN MATRIISI $^{1}$
}

$\mathrm{M}$ ytologiantutkimuksessa on viime vuosikymmeninä enenevästi kamppailtu perinteen variaatioon ja sen tulkintaan liittyvien ongelmien kanssa. Ongelmat liittyvät mytologian (tai ainakin joidenkin sen elementtien) pitkäaikaiseen jatkuvuuteen, jolloin variaatio on väistämätöntä. On myös pohdittu, mitä tapahtuu, kun erityyppiset maailmankuvan mallinnustavat kohtaavat, olipa kyse sitten uskonnollisesta kääntymyksestä tai modernisaatiosta. Aivan äskettäin variaatiota on tarkasteltu myös hienosyisemmin, kun on havaittu, että mytologia voi muunnella jopa saman yhteisön sisällä eri kulttuuristen käytänteiden puitteissa eri tavoin. Tämäntyyppinen variaatio osoittaa, että monet mytologiaa koskevat peruskäsityksemme ovat ongelmallisia. Tarkoitukseni on hahmotella tässä katsauksessa lähestymistapaa mytologian variaation tutkimukselle. Mytologiaa lähestytään käsitteen symbolinen matriisi puitteissa. Käsite viittaa mytologian rakenne-elementteihin ja tapoihin, joilla niitä yhdistellään (ks. myös Frog 2014a ja 2014d). Aluksi kerron, mitä mytologialla tässä yhteydessä tarkoitetaan, ja mihin täsmälleen viittaan termillä symbolinen matriisi. Hahmottelen myös matriisin elementtien eli osatekijöiden eri tyyppien (kuvat, motiivit jne.) välisiä muodollisia eroja, jotka huomioon ottamalla on helpompi havaita ja analysoida yksittäisten tapausten variaatiota. Annan esimerkkejä sekä eri uskontojen kohtaamisissa kehkeytyvästä näkökulmien variaatiosta suhteessa mytologisiin symboleihin että erilaisiin sosiaalisiin käytänteisiin liittyvästä näkökulmien variaatiosta. Lopussa esitän mytologian rekistereihin lähestymistavan, joka huomioi variaation tyypit saman ilmiön eri muotoina.

\section{ONGELMA}

Ennen kuin paneudun synkronisen variaation kysymyksiin, haluan nostaa esiin mytologian pitkäkestoisuuden sekä mytologiassa ilmenevän sosiaalisperustaisen variaation, joka on pitkään jatkuneen käytön tulosta. Tämä historiallinen kesto vastaa kielen historiallista ikää, minkä vuoksi on järkeenkäypää puhua vaikkapa "indoeurooppalaisesta mytologiasta" tai "uralilaisesta mytologiasta": mytologian symbolit ja rakenteet osoittavat vuosituhantista jatkuvuutta aivan samalla tavoin

$1 \quad$ Artikkelin kirjoittaja on tutkijatohtori Suomen Akatemian rahoittamassa tutkimusprojektissa Oral Poetry, Mythic Knowledge and Vernacular Imagination: Interfaces of Individual Expression and Collective Traditions in Pre-modern Northeast Europe (2012-2016). 
kuin kielen sanat ja kielioppi. ${ }^{2}$ Kieli ja mytologia ovat liittyneet toisiinsa kautta kulttuurien historian jo ennen kuin niitä on dokumentoitu tuntemissamme muodoissa. Tämä ei tarkoita, että unkarilainen ja suomalais-karjalainen mytologia olisivat enää sen lähempänä toisiaan kuin kyseiset kieletkään, eikä tämä tarkoita sitä, että mytologia olisi yhtään homogeenisempi kuin kieli. Anna-Leena Siikala (2012, 15) on esittänyt mytologian ja kielen väliseen analogiaan pohjautuen, että tämäntyyppisen variaation yhteydessä olisi itse asiassa puhuttava mytologian "murteista" samalla tavoin kuin puhumme kielen murteista. Analogia tarjoaa arvokkaan välineen mytologian variaation pohtimiseen.

Kielet ja murteet eivät synny eristyksissä: niitä muokkaavat lainat ja muunlaiset eri kielten ja murteiden vaikutukset. Vastaavasti kosketukset toisiin mytologioihin ja näihin liittyviin käytänteisiin vaikuttavat myös mytologioihin. Tällaisia prosesseja on tavallisesti pohdittu viitekehyksissä, joissa mytologiaa lähestytään enemmän tai vähemmän koherenttina ja homogeenisena järjestelmänä irrallaan muista mytologioista - paljolti samoin kuin maallikko käsittää kielen omana järjestelmänään, jolla on oma sanastonsa ja kielioppinsa. Tästä johtuen kristinuskon kuvitellaan kohdanneen enemmän tai vähemmän koherentin mytologian ja uskonnon saapuessaan Suomeen tai Skandinaviaan. Kohtaamisten seurauksena kehkeytyneitä uskomusten yhdistelmiä on kuvattu termeillä synkretismi ja uskonnollinen pluralismi, jotka on käsitetty ikään kuin kahden idealisoidun uskonnon ja mytologian kreolisaatioksi. Tutkijat ovat yrittäneet selvittää, mitkä elementit juontuvat mistäkin uskonnosta tai kuinka ne toimivat yhdessä. Tällainen lähestymistapa kuitenkin helposti marginalisoi ja aliarvioi kohtaamisen (tai törmäyksen) tuloksen, joka vaikuttaa erheeltä kahden idealisoidun kuvan välillä. Haluan nostaa tässä esiin eritoten eri mytologioiden sosiaalisen tulkinnan, joka johtaa siihen, että inmiset omaksuvat tai manipuloivat johonkin tiettyyn näkökulmaan liittyneitä mytologian symboleja eri näkökulmista. Eri näkökulmat voivat edustaa eri uskontojen näkökulmia, kuten kristittyjen ja ei-kristittyjen kohtaamisessa, mutta myös esimerkiksi eri kansanryhmien tai asiantuntijoiden näkökulmia, jotka niin ikään poikkeavat toisistaan saman (tai oikeammin samaksi olettamamme) mytologian suhteen.

\section{MYYTTINEN DISKURSSI JA SYMBOLINEN MATRIISI}

Termejä myytti ja mytologia on määritelty monin tavoin. Yleisesti ottaen lähestymistapojen voidaan nähdä kuuluvan kolmeen laveaan kategoriaan tai näiden yhdistelmiin. Klassinen tapa on määritellä myytti tietyntyyppiseksi kertomukseksi³ ${ }^{3}$ mikä

$2 \quad$ Mytologioiden käsittely tällä tavoin jakaa ne kielellisen perinnön mukaisiin ryhmiin ja näin ollen korostaa kyseisten ryhmien välisiä suhteita, mikä ei välttämättä edellytä mytologian jonkin aiemman muodon rekonstruktointia. Mikä hyvänsä pitkän keston jatkuvuus liittyy tietenkin mytologian historiaan ja siihen, mitä tämä mytologia oli varhaisempina aikoina. Tämän vuoksi indoeurooppalaisen kantakielen (esim. West 2007; Lyle 2012) ja uralilaisen kantakielen (esim. Napolskih 1992; Hoppál 2010, 28-37) puhujien mytologiasta voidaan sanoa varsin erityyppisiä asioita. Viime aikoina mytologian elementteihin ja sykleihin on tarjottu näkökulmia, joilla voi olla juuret huomattavasti aiempaa oletettua varhemmassa menneisyydessä, kivikaudella (esim. Meletinskij 1997; Napolskih 2012; Witzel 2012). Huomio voidaan vaihtoehtoisesti kiinnittää mytologian "makroalueellisiin komplekseihin", jotka ovat alueellisia kaavamaisuuksia ja järjestelmiä jotka kehittyvät sellaisilla alueilla, joilla erilaisilla mytologisilla perinnöillä on pitkä vuorovaikutushistoria (Witzel 2012, 65-68; esim. Frog 2011; 2014a).

3 Lähestymistavan perustana on modernin termin myytti alkuperä. Termi lainattiin klassisen kreikan sanasta mythos romantiikan aikakaudella käsitteeksi, jota käytettiin pakanallisiin 
tavallisesti johtaa mytologian hahmottamiseen ikään kuin kertomusmaailmana, jossa jumalilla ja heidän vastustajillaan on kerronnan logiikan mukaisia seikkailuja. Lähestymistapa tuottaa ongelmia esimerkiksi silloin, kun jumalaa käsitellään rituaalissa eikä kertomuksissa, kuten on laita Äkräksen, nauriiden ja muiden juuresten jumalan suhteen. Toisen lähestymistavan taustalla on käsitys mytologiasta eräänlaisena sosiaalisen, empiirisen ja näkymättömän maailman mallintamisjärjestelmänä, joka kuvaa kuinka nämä maailmat toimivat ja miksi ne ovat sellaisia kuin ovat. ${ }^{4}$ Näkökulman puitteissa myyttejä tarkastellaan symbolisina sosiaalisen viitekehyksen tarjoavina malleina, tai ne tunnistetaan ja käsitetään yleisemmällä tasolla merkityksellisiksi tai olennaisiksi (esim. hyvän ja pahan välinen taistelu). 1990-luvun alusta alkaen on kehittynyt kolmas keskeinen lähestymistapa, jonka piirissä ei olla niinkään pyritty määrittelemään myyttiä tai mytologiaa, vaan keskitytty sen sijaan myyttiseen diskurssiin ${ }^{5}$ eli siihen, kuinka ihmiset ovat käyttäneet ja manipuloineet olemukseltaan myyttisiä kuvia, motiiveja ja kertomuksia välittääkseen käsitteellisiä malleja, arvoja, käsityksiä ja niin edelleen.

Myyttisen diskurssi on tullut suosituksi suuntauksissa, joissa on kiinnitetty huomiota merkityksiin ja performanssiin, ja joissa mytologiaa on tarkastelu symbolien järjestelmänä ja symboleja näin ollen mytologian osatekijöinä. ${ }^{6}$ Symbolina tai merkkinä - merkityksellisenä yksikkönä - voidaan pitää mitä tahansa mytologiaan liittyvää tai viittaavaa yksityiskohtaa, kokonaisuutta tai mielleyhtymää. Tällaisia yksikköjä voivat edustaa esimerkiksi jumalan kuva, kerrontamotiivi tai jopa mutkikas kertomus. Näiden symbolisten osatekijöiden tyyppejä esitellään seuraavassa osiossa. Tässä yhteydessä on tärkeää pitää mielessä, että mytologia merkitsee enemmän kuin pelkkää kertomusta; se koostuu kaikenlaisista symbolisista osatekijöistä ja näiden yhdistelemisen konventioista. ${ }^{7}$ Symbolien ja niiden yhdistelemisen konventioista muodostuu symbolinen matriisi.

uskontoihin liitetyistä kertomuksista (esim. Eliade 1968 [1963], 1-2; Doty 2000, 4-30; myös pohdinta teoksessa Csapo 2004). Myytin varsinaiset määritelmät ovat silti moninaisia (esim. Eliade 1968 [1963], 5-6; Lévi-Strauss 1967 [1958], 202-228; Barner-Barry \& Hody 1994; ks. myös Rowland 1990 ja Briggs \& Bauman 1992).

4 Lähestymistapa kehittyi, kun alettiin kiinnittää huomiota mytologian ja ihmisten todellisuuskäsitysten välisiin suhteisiin (esim. Cassirer 1925), mikä johti Bronislaw Malinowskin esitykseen, jonka mukaan myytti "ei ole pelkkä kertomus vaan elettyä todellisuutta" (1926, 100). Semiotiikka on ollut keskeisessä roolissa nykyisten tämäntyyppisten lähestymistapojen kehityksessä. Lähestymistavat ovat osoittautuneet käyttökelpoisiksi läntisten kulttuureiden myyttien käsittelyssä (erit. Barthes 1972 [1957]). Entistä hienostuneemmat erottelut ovat välttämättömiä, mikäli näiden lähestymistapojen avulla käsitellään esimerkiksi jumalia ja jumalkertomuksia perinteisissä mytologioissa, kuten olen esittänyt toisaalla (Frog 2014a; 2014c; 2014d).

5 Termi ja käsite myyttinen diskurssi omaksuttiin nopeasti mytologian ja uskonnon tutkimukseen (esim. Siikala 1992). Myyttistä diskurssia on käytetty yleisemmin, kun on oltu kiinnostuneita siitä, millaisessa vuorovaikutuksessa inmiset ovat emotionaalisesti latautuneiden symboleiden kanssa (esim. Goodman 1993), joskin termiä käytetään useimmiten ilman sen tarkempia määritelmiä.

6 Myös tutkijat, jotka määrittävät myytin kertomukseksi, saattavat käyttävää myyttisen diskurssin käsitettä (esim. Witzel 2012,17); vastaavia ajatuksia on implisiittisesti sellaisissa mytologioiden kuvauksissa, joissa mytologioiden esitetään koostuvan asioista, jotka ovat ajattelun hyödykkeitä (bonnes à penser; Lévi-Strauss 1962, 128), tai jotka ovat "tietämisen tapa" (Doty 2000, 55-56). Tiettyjä abstrakteja rakennekaavoja voidaan tarkastella merkkeinä, sillä ne ovat diagrammaattisesti ikonisia: kaavan tunnistaminen vastaa sen merkityksellisyyden tunnistamista, vaikka kuvat ja motiivit, joista kaava koostuu, vaihtelisivatkin huomattavasti. 
Kun tutkimuksessa lähestytään jonkin tietyn ympäristön symbolista matriisia, tulee kiinnittää huomiota erityisesti kolmeen tekijään. Ensinnäkin mytologian ja sen symboleiden käsittely tulisi erottaa uskosta. Suomen kielen "usko" liittyy keskusteluihin uskonnosta ja kansanuskosta. Usko on kuitenkin subjektiivinen yksilötason ilmiö, ja kristinuskon vaikutuksesta uskominen kuvitellaan yleensä tietoiseksi uskon allekirjoittamiseksi. Mytologia mahdollistaa kuvitteelliset käsitykset maailmasta ja kokemuksesta; se ulottuu kokemuksellisen maailman ulkopuolelle mentaalisiin malleihin, jotka liittyvät kuitenkin tähän maailmaan mielikuvituksen kautta. Mytologia eroaa toisista mentaalisten mallien tyypeistä esimerkiksi poeettisten metaforien emotionaalisen latautumisen suhteen. (Doty 2000, 55-58). Mentaalisiin malleihin turvautuminen ei ole tietoinen valinta: se, että joku ei usko kummituksiin, ei merkitse, etteivätkö kummitustalossa yöllä kuuluvat oudot äänet hermostuttaisi tai pelottaisi häntä (ks. Kamppinen 1989, 18-19). Mytologian osatekijöitä voidaan kuvata emotionaalisesti latautuneiksi symboleiksi, koska ne ovat sosiaalisesti väkevän merkityksellisiä, olivatpa ne niin vakiintuneita että toimivat tiedostamattomina oletuksina tai kyseenalaistettiinpa niitä aktiivisesti yhteisöissä tai yhteisöjen välillä. ${ }^{8}$ Emotionaalisen latauksen tunnistaminen ei edellytä henkilökohtaista symbolin hyväksymistä: esimerkiksi marttyyriuden symbolit kirjallisuudessa voivat helposti herättää vastakaikua ateistissakin. Symboleja käytetään ja manipuloidaan juuri siksi, että niiden emotionaalinen lataus tunnistetaan. Toisekseen, myyttisiä symboleita voi yleisesti luonnehtia monitulkintaisiksi: niitä voidaan tulkita joustavasti vaihtelevin tavoin. Kolmannekseen, tietyn kulttuuriympäristön symbolinen matriisi koostuu kaikista relevanteista symbolisista resursseista, kuten alla tullaan havainnollistamaan.

\section{MYYTTISEN DISKURSSIN OSATEKIJÄT}

Tutkittaessa myyttistä diskurssia ja mytologian symbolista matriisia on hyödyllistä eritellä symbolisten osatekijöiden muototyypit, joita ovat kuva, motiivi, teema, kertomuskaava ja juoni tai juonityyppi. Termejä kuva ja motiivi käytetään usein varsin löyhästi ja jossain määrin vaihtoehtoisina termeinä. Määrittelen kuvan staattiseksi osatekijäksi, joka vastaa kieliopin substantiivia. ${ }^{9}$ Motiivi sen sijaan vastaa verbiä ja käsittää muutoksen tai määrittää kahden tai useamman kuvan keskinäisen suhteen. ${ }^{10}$ Kuvan ja motiivin erittely ja käsitteellistäminen luovat kehyksen, jonka puitteissa myyttisen diskurssin variaatiota voidaan tutkia. Esimerkiksi UKKONEN ISKEE PAHOLAISEEN ${ }^{11}$ on tavallinen motiivi Itämeren alueella (esim. Uther 1997-1999, 763). Tässä motiivissa UKKONEN kuvaa paikallisen jumalan, kuten Ukon, roolia. PAHOLAISEN

8 Doty (2000, 137-140) on käsitellyt tämäntyyppistä variaatiota myytin vitaalisuuden asteen tekijänä.

9 Mielikuvista ja kuvaskeemoista ks. esim. Lakoff 1987: passim; myyttisistä kuvista ks. Siikala 1992, 42-50.

10 Olen kehittänyt tämän motiivin määritelmän käytännön analyysin välineeksi. Motiivi on alun perin määritelty varsin intuitiivisesti, ja sen käyttö on ollut äärimmäisen epäyhtenäistä. Stith Thompsonin Motif-Index of Folk-Literature (1955-1958) ei selventänyt tätä johtuen Thompsonin omasta tulkintatavasta: "Kertojat käyttävät tiettyjä kerronnan yksiköitä toistuvasti; ne ovat ainesta, josta kertomukset on tehty. Sillä ei ole merkitystä, millaisia ne tarkalleen ovat; mikäli ne ovat käyttökelpoisia kertomusten rakentamisessa, pidän niitä motiiveina." (1955, 7, kursivointi Frog).

11 Thompsonin motiivityyppi A62.2. Thunder and Lightning Slay Devils. 
osan voi täyttää mikä tahansa relevantti vastustajan kuva. ${ }^{12}$ UKKONEN ISKEE PAHOLAISEEN - motiivi toimii monen tarinan ytimenä. Motiivi liittyy myös tabuihin ja näiden yhteydessä ilmeneviin traditioihin, esimerkiksi perinteeseen, joka neuvoo kuinka välttää salamanisku. Jälkimmäisessä kontekstissa UKKONEN ISKEE PAHOLAISEEN voidaan nähdä immanenttina motiivina - toisin sanoen motiivi voi manifestoitua todellisuudeksi tai kokemukseksi aina, kun ukkostaa. Motiivi on kosketuksissa lukuisiin muihinkin motiiveihin, kuten PAHOLAINEN PAKENEE UKKOSTA, joka vuorostaan assosioituu esimerkiksi motiiviin PAKENEVA PAHOLAINEN PIILOUTUU TALOON. Viimeisin motiivi assosioituu vuorostaan varautumistoimiin, kuten ikkunoiden ja ovien sulkemiseen ukonilmalla, jotta vältyttäisiin salamaniskulta. Tällaiset toimet taas heijastelevat immanenttia motiivia UKKONEN ISKEE TALOON, JOSSA ON AVOIN IKKUNA TAI OVI ( $\leftarrow$ PAHOLAINEN PIILOUTUU TALOON), joka liittyY UKKONEN ISKEE PAHOLAISEEN -motiivia ympäröivään motiivijärjestelmään.

UKKONEN ISKEE PAHOLAISEEN -motiivia ympäröivä järjestelmä on kehittynyt sen periaatteen varaan, että UKKOSEN ja PAHOLAISEN kuvilla on toimijuus. Yksittäiset tähän järjestelmään kuuluvat motiivit ja kertomukset, jotka rakentuvat uKKOSEN ja PAHOLAISEN kuvien varaan, saattoivat kulkeutua Itämeren alueen kulttuurien välillä suhteellisen helposti, sillä näillä kulttuureilla oli sama yleinen viitekehys (esim. Uther 19971999, 763). Kansanomaiset UKKOSEN ja PAHOLAISEN kuvat saatettiin yksinkertaisesti sijoittaa perinteissä sopiviin osiin, jolloin motiivi olisi merkityksellinen mytologian symbolisessa matriisissa (Frog 2013b, 110). Modernisaation myötä moniin ilmiöihin alkoi kiinnittyä vaihtoehtoisia kuvia. Esimerkiksi ukonilman syyksi määriteltiin ilmamassojen liike ja törmäykset. Nämä vaihtoehtoiset kuvat riistivät UKKOSELTA toimijuuden, mikä taas vei pohjan traditiossa keskeiseltä motiivilta UKKONEN ISKEE PAHOLAISEEN. Vaikka tämän keskeisen motiivin perustan murenemisen voisi kuvitella hajottavan koko järjestelmän sen ympäriltä, näin ei kuitenkaan tapahtunut, kuten Ülo Valk (2012) on hiljattain kuvannut virolaisia perinteitä käsittelevässä tutkimuksessaan.

Kuten yllä hahmotellusta mallista käy ilmi motiivit, kuten UKKONEN ISKEE TALOON, JOSSA ON AVOIN IKKUNA TAI OVI, säilyttävät elinvoimaisuutensa, mikäli niihin liittyy emotionaalinen lataus: vaikka käsitys ukonilmasta muuttui, salamaniskulta on edelleen pyritty välttymään perinteisten varotoimien avulla! Sen sijaan, että olisi muutettu käyttäytymistä strukturoivia motiiveja, motiivi tulkittiin uudelleen. Ukkosen kuva liitettiin uusiin, ukonilman perusperiaatteisiin liittyviin motiiveihin, kuten ILMAN LIIKKUMINEN HOUKUTTELEE UKKOSTA, jonka logiikalle monet immanentit motiivit perustuvat, esimerkiksi UKKONEN ISKEE TALOON, JOSSA ON AVONAINEN IKKUNA $(\leftarrow$ AVONAINEN IKKUNA SAA ILMAN LiIKKumAan talossa) (esim. Valk 2012, 43, 53, 61, myös 56, 59; Frog 2014d, 67). Esimerkki kuvaa myyttistä diskurssia silloin, kun yksilön käyttäytymisen ja hänen maailman toimintaperiaatteisiin liittyvien käsitystensä välistä suhdetta punnitaan tai siitä käydään neuvotteluja. Samalla esimerkki kuvaa hyvin mytologian pienimpien osatekijöiden välisiä suhteita ja sitä, miksi niiden erittely on hyödyllistä variaatiota tutkittaessa.

Motiivit edustavat kerronnan, toiminnan tai kokemuksen pienimpiä yksikköjä. Tutkimuksessa motiivia on toisinaan käytetty merkitsemään yhteisössä kiertäviä

12 Toisin sanoen PAHOLAISEN osan täyttävä kuva voi olla keskittymätön symboli - symboli, joka toimii yleisnimenä ("paholainen") erotuksena erisnimestä ("Saatana") (keskittymättömistä symboleista ks. myös Frog 2014a; 2014d). 
moniosaisia tai -tasoisia kerronnan osatekijöitä, mutta näitäkin tekijöitä on usein hyödyllistä eritellä. Kompleksisemmat osatekijät, jotka on luotu niihin konventionaalisesti assosioiduista kuvista, motiiveista ja / tai näiden yhdistelmistä, voidaan eritellä teemoiksi. ${ }^{13}$ Esimerkiksi Lemminkäisen virressä sankari kohtaa ja ohittaa matkallaan liudan vaaroja (ks. Frog 2010, 377-395), joista jokaista voi käsitellä kohtaamisen, ratkaisun ja matkan jatkamisen motiiveista rakentuvana teemana (esim. Frog 2013b, 106-108). Toisiaan seuraavat teemat ovat tavallisesti rakenteellisesti yhdenmukaisia, ja ne varioivat ainoastaan keskenään vastaavien kohdattavien vaarojen kuvissa (esim. TULINEN, KOKKO, MUSTA MATO, SUDET RAUTASUITSILOISSA), joista jokaiseen liittyy relevantti vaaranselvittämismotiivi (esim. Frog 2014e, 196-198). Vaaran kuva tai motiivi, joka kuvaa sen selvittämistä, voikin varioida turmelematta itse teemaa. Myös kokonainen teema on myyttisessä diskurssissa manipuloitavissa. Esimerkiksi Lemminkäisen virteen kuuluu teema noitien kaksintaistelusta, jossa sankari ja hänen vastustajansa "laulavat" vuorotellen esiin sarjan apuhenkiä, ja jossa sankari voittaa. Yhdessä poikkeustapauksessa laulaja muuttaa Lemminkäisen ja tämän vastustajan roolit niin, että sankari häviää (SKVR VIII 839) ja tuo näin esiin vaihtoehtoisen sankarin kuvan.

Kuvien ja motiivien lailla myös kokonaiset teemat voivat vaihtaa paikkaa. Noitien kaksintaistelu -teema tavataan eräässä paikallisessa Kilpalaulannan variantissa, jossa se on korvannut Väinämöisen ja Joukahaisen välisen tietävämmyyskilvan teeman (SKVR II 33; 34a-b; 36). Tämä tapaus on kiinnostava, koska se on ainoa variantti, jossa kyseiset taistelut ovat vaihtaneet paikkaa. Ne näyttävät pysyneen erillään, koska häiriköivä Lemminkäinen on samastettu noidan tai šamaanin harjoittamaan magiaan, kun taas Väinämöinen on samastettu tietäjälle tyypilliseen mahtiin ja magiaan (Frog 2010, 191-196; ks. myös Frog 2013c). Tämä paikallinen variantti ei kuitenkaan välttämättä heijasta kilpailevia mytologiakäsityksiä per se. Sen sijaan variantti voi olla oire siitä, että noidan ja šamaanin rooleihin on alettu liittää erilaisia merkityksiä, tai siitä, että epiikka menetti myyttistä arvoaan.

Kertomuskaava on elementtien (kuvien, motiivien, teemojen ja / tai näiden yhdistelmien), niiden järjestyksen ja niiden välisten suhteiden kokonaisuus, joka muodostaa yhtenäisen tekstijakson, vaikkei välttämättä muodostaisikaan kertomuskokonaisuuden kattavaa juonta. Konventionaalinen juoni tai juonityyppi on kokonaisen, komplikaatiosta ratkaisuun päätyvän kertomuksen kertomuskaava. ${ }^{14}$ Esimerkiksi ukkosinstrumentin varkaudesta kertovat perinne, joka on määritetty kertomustyypiksi ATU 1148b (Uther 2004 II, 48-50), on kompleksinen juonityyppi, jota luonnehtii kaksi toisiinsa liittyvää kertomuskaavaa. Kertomuksen aloittava kertomuskaava kertoo ukkosenjumalan ukkosta tuottavan esineen (ukkosen kuva) varkaudesta ja kätkemisestä; toinen kertomuskaava kertoo tämän jumalan

13 Termin motiivi tavoin myös termiä teema on käytetty lukuisin tavoin ja useimmiten ilman selkeitä formaaleja kriteerejä sen erottamiseksi toisista rakenteellisista yksiköistä (esim. Propp 1968 [1928], 12-13; Arend 1933; Lord 1960, 68-98; Frye 1968).

14 Tätä erittelyä ei ole tehty Aarne-Thompson-Utherin (ATU) kansainvälisten kansansatujen kertomustyyppiluettelossa (Uther 2004 tai aiemmat editiot), joka keskittyy näennäisesti juoneen, vaikka kyseessä voi olla kerronnallisen kaavan ja juonen yhdistelmä. Jotkut ATU-kertomustyypit näyttävät kuitenkin ilmenevän tavallisesti ainoastaan episodeina mutkikkaammissa kertomuksissa ilman erottuvaa komplikaatiota ja / tai ratkaisua, joiden perusteella ne muodostaisivat juonen siten kuin se on määritelty tässä (esim. ATU 1087). 
Frog: Myyttinen diskurssi ja mytologian symbolinen matriisi

[http://www.elore.fi/arkisto/1_15/frog.pdf]

seikkailu(i)sta, jo(i)ssa hän saa varastetun ukkosen takaisin ja peittoaa vastustajansa (UKKONEN ISKEE PAHOLAISEen). ${ }^{15}$ Silloin kun juonityyppi on tallennettu, uKKosen kuva musiikillisena esineenä ei vastannut useimmissa kyseisissä kulttuureissa vallitsevia ukkosen olemusta kuvaavia syntytarinoita (Frog 2011, 80; myös Frog 2014b, 125-134). Juoni oli myös jäämässä käytöstä tai sitä sovellettiin toisissa yhteyksissä (Frog 2011, 81-91). Yksi esimerkki Virosta esittää kertomuksen avausjakson, jossa paholainen varastaa jumalan "instrumentin" (pill), mutta kertoja päättää kertomuksen äkkiä tähän ja selittää sen kuvaavan paholaisen liittymistä säkkipilleihin (torupill) ilman yhteyttä uKKoseen (Loorits 1932, 63-64). Versio on voitu tarkoittaa humoristiseksi, mutta sen voidaan joka tapauksessa nähdä haastavan ATU 1148b -tradition ja kuvan, jonka mukaan ukkonen on lähtöisin instrumentista (pill). Esimerkki osoittaa, miten kertomuskaavaa voidaan soveltaa yhtäältä episodissa ja toisaalta kokonaisessa juonityypissä, ja myös, miten kaava voi varioida erityyppisten osatekijöiden kesken (tässä kertomuskaavaa on sovellettu kokonaiseen juoneen). Kun pohditaan variaatiota myyttisessä diskurssissa, on varsin tärkeä eritellä osatekijöiden laajuutta ja kompleksisuutta, jotta variaation dynamiikkaa ja potentiaalisia merkityksiä pystytään arvioimaan.

\section{VAIHTOEHTOISET JA VAIHTUVAT NÄKÖKULMAT}

Myyttistä diskurssia on erittäin mielenkiintoista tarkastella radikaalin kulttuurisen muutoksen konteksteissa. Vaikka modernisaatio on äärimmäisen kiinnostava muutosprosessi, sen puitteissa ei voida kovin hyvin kuvantaa symbolista matriisia. Nykyään olemme tottuneita näkemään mytologian erillään tieteestä, minkä vuoksi esimerkiksi säHKöN, muiden myyttisten kuvien, motiivien ja näihin liittyvien kompleksisten osatekijöiden tunnistaminen mytologian puitteissa on vaikeaa. (Ks. Frog 2014d.) Historiallisesti ja kulttuurisesti etäisiä konteksteja on tässä suhteessa helpompi tarkastella objektiivisesti. Keskiaikaiseen kristillistymiseen liittyvän myyttisen diskurssin historiallinen etäisyys tekee siitä käyttökelpoisen kulttuurisen muutoksen symboliselle matriisille aiheuttamien vaikutusten kuvaamiseen.

Käyttämäni lähestymistavan mukaan kristinuskon saapuminen pohjoiseen ei ollut prosessi, jossa selvärajainen uskonto syrjäytti toisen. Sen sijaan uusi uskonto lisäsi matriisissa käytettävissä olevien symbolien määrää. Kristityt ja pakanat eivät olleet tietämättömiä toistensa mytologioista, vaan he pystyivät aktiivisesti hyödyntämään toistensa symboleja resurssina myyttisessä diskurssissaan. Kohtaaminen on tuottanut varsin poikkeuksellisia kertomuksia, jotka sijoittuvat mytologioiden välimaastoon. Esimerkiksi eräs muinaisislantilainen saaga kuvaa lähetyssaarnaajan ja pakanapapittaren välistä yhteenottoa, jossa papitar kertoo, kuinka ukkosenjumala Thor kerran haastoi Jeesuksen taisteluun, mutta Jeesus oli liian pelkurimainen tullakseen paikalle (Njáls saga, luku 102). Saagassa voidaan nähdä uusi juoni, joka syntyi yhdistämällä kuvia (THOR, JeEsus) ja varioimalla yhteenottomotiivia, joka normaalisti, muissa Thorista kertovissa myyttisissä kertomuksissa, johtaa motiiviin UKKONEN ISKEE PAHOLAISEEN. Uusi juoni luo suhteen jumalten kuvien ja samalla

15 Tämän perinteen lähteistä ks. Frog 2011; yksityiskohtaisemmin ongelmallisemmasta skandinaavisesta aineistosta ks. Frog 2014b. 
niille leimallisten ideologioiden ja elämäntapojen ${ }^{16}$ välille. Jo pitkään on ajateltu, että Väinämöisen tuomio, jossa kristuksenomainen lapsi karkottaa Väinämöisen, syntyi ja vakiintui vastaavalla tavoin (esim. Kuusi 1963, 320). ${ }^{17}$ Tämänkaltaiset esimerkit tuovat esiin, kuinka yksilöt voivat hyödyntää kaikkia käytettävissään olevia resursseja, ja kuinka he näkevät yksittäiset symbolit omasta näkökulmastaan. Näitä näkökulmia voidaan lähestyä matriisin sisäisinä positioina, ja sosiaalisesti vakiintuneiden positioiden voidaankin nähdä luonnehtivan uskontoja - toisin sanoen matriisin symbolien muodostamien ryvästen, kokonaisuuksien tai järjestelmien yhdenmukaistaminen, tulkinta ja arvottaminen voidaan katsoa luonteenomaiseksi uskonnoille. On syytä myös huomata, ettei yksilön ole edes mahdollista hyödyntää kaikkia matriisissa käytettävissä olevia symboleja, mikä osaltaan lisää symbolien monitulkintaisuutta.

Jumalten kuvat ovat symboleja, jotka nähdään usein luonteenomaisiksi uskonnolle ja sen mytologialle, minkä vuoksijumalat ovat myyttisen diskurssin pääkohteita. Siinä missä Thorin ja Jeesuksen esimerkki asetti nämä kahden eri mytologian jumalat tiettyyn keskinäiseen suhteeseen, näitä symboleita voidaan tulkita toisten strategioiden avulla. Odin tarjoaa mielenkiintoisen esimerkin symbolien uudelleentulkinnoista. ${ }^{18}$ Valeasut ja sankareiden kohtalon (ja kuoleman) järjestely luonnehtivat Odinia kansanomaisessa mytologiassa. Kristityt kirjoittajat käyttivät näitä vakiintuneita motiiveja ja ohjasivat niiden tulkintaa perustellakseen petoksen ja manipulaation Odinin pääasiallisiksi piirteiksi pakanajumalana. Kirjoittajat saattoivat myös hyödyntää motiiveja, jotka olivat tuttuja kristillisessä diskurssissa, kuten PAHOLAINEN HOUKUTteleE KRISTITTYä. Näin he sijoittivat Odinin kuvan PAHOLAISEN rooliin, mikä vastavuoroisesti kertoo Odinin arvotuksesta ja tulkinnasta. Odinin ja kristillisen paholaisen välinen suhde voitiin eksplikoida myös esittämällä, että paholainen oli ottanut Odinin hahmon. Nämä strategiat liittyvät symbolisen matriisin laajentumiseen, joka tarjosi kristityille mahdollisuuden manipuloida kansanomaisen uskonnon symboleja.

Kaikkien kansanomaisten uskontojen symbolit eivät olleet aina keskiaikaisten kristittyjen käytettävissä. Esimerkiksi Nestorin kronikassa kuvataan myös ei-kristillisten velhojen tai pappien välisiä kohtaamisia. Yllä mainitut skandinaaviset kuvaukset ja itse tapahtumat ovat ajallisesti etäällä toisistaan, mutta niiden kirjoittajat ovat lähinnä kiinnostuneita oman yhteisönsä historiasta ja tapahtumista (enemmän tai vähemmän) tutuissa paikoissa. Nestorin kronikka kertoo historiallisesti kaukaisista tapahtumista maantieteellisesti etäisissä paikoissa kuten Valkeajärvellä, missä pakanat edustavat oletettavasti uralilaista kieltä puhunutta yhteisöä, joka on myös kulttuurisesti etäällä kirjoittajista. Jotkut pakanauskonnon

16 Kansanomaisessa kielessä ei ollut vastineita nykyiselle terminologialle, jolla puhutaan uskonnosta, uskonnollisesta konfliktista ja uskonnollisesta muutoksesta, minkä vuoksi käytettiin ilmaisuja, kuten inn forni siðr ('vanhat tavat') vastakohtanaan inn nýi siðr ('uudet tavat') eli Kristinn siðr ('kristilliset tavat') (Cleasby \& Vigfússon 1896, 526; kansanomaisen ja kristillisen uskonnon välisestä vuorovaikutuksesta kääntymyksen kontekstissa Aðalsteinsson 1978; Miller 1991; Sanmark 2004; Gunnell 2009).

17 Tämä tulkinta on myös Elias Lönnrotin Kalevalan rakenteen taustalla: Väinämöisen tuomio on sijoitettu eepoksen loppuun merkitsemään pakanamenneisyyden loppua ja kristillisen aikakauden alkua.

18 Aineistoista ja keskusteluista mukaan lukien alla mainitut tyypit, ks. Kaplan 2011; Lassen 2011. 
spesialisteista on taivuteltu myöntämään, että heidän jumalansa on nimeltään "Antikristus" ja jopa kuvaamaan jumaliaan kristillisinä HeLvetin demonien kuvina. ${ }^{19}$ Onkin hyvä pohtia, onko tämäntyyppisessä esimerkissä kyse myyttisen diskurssin kohteena olevan kulttuurin symbolien (kuten yllä Odinin tapauksessa) manipulaatiosta, ainoastaan lähdekulttuurin symbolien manipuloinnista (mikä vaikuttaa luultavalta tapauksessa, jossa pakanajumalaa kuvataan "Antikristukseksi") vai jopa näihin liittymättömän kolmannen kulttuurin symbolien manipulaatiosta. ${ }^{20}$ Lisäksi kulttuurit konstruoivat toisista ryhmistä sekä näiden mytologiasta ja uskonnosta konventionaalisia, tavanmukaisia tulkintoja. Näiden tulkintojen tuottamista kuvista voi tulla mytologian osatekijöitä, mikä voi myös vaikuttaa siihen, kuinka mytologian eri osatekijät ymmärretään. ${ }^{21}$

Joissakin tapauksissa myyttisessä diskurssissa on voitu manipuloida myyttisen kertomuksen koko juonityyppiä. Näin näyttää tapahtuneen keskiaikaisessa Islannissa yllämainitun ukkosinstrumentin varkauden (ATU 1148b) kohdalla. Kyseistä kertomustraditiota tavataan balttilais-, germaani-, saamelais- ja suomalaiskulttuureista, ja se liittyy yleensä erityisesti motiiviin UKKONEN ISKEE PAHOLAISEEN sekä monissa eri motiiveissa ilmeneviin käsityksiin uKKosen ja hedelmällisyyden ja / tai elämän välisestä suhteesta. 1200-luvulta peräisin olevassa Edda-runossa, Prymskviða, tavataan kertomuksesta versio, joka eroaa muualla tavatuista kyseisen tradition edustajista tietyin olennaisin osin. Erityisen huomionarvoista on, että a) Thor on passiivinen pikemmin kuin toiminnan järjestelijä; b) motiivista JUMALA PUKEUTUU VALEASUUN, joka liittyy varastetun UKKOSEN takaisinsaamiseen, on tässä ainutlaatuinen versio, jonka mukaan jumala painostetaan pukeutumaan hääasuiseksi jumalattareksi, mikä puolestaan on yksiselitteisesti ymmärrettävissä jumalan nöyryyttämiseksi sukupuolirajan rikkomisen vuoksi; ja c) kertomus vaikuttaa irronneen tyystin uskomusperinteistä: jumalan vaunut aiheuttavat edelleen ukkosta ja salamointia hänen matkustaessaan (morsiameksi pukeutuneena), eikä vastustaja osoita pelkoa tätä ukkosta tai varastettua esinettä (Thorin vasaraa) kohtaan, mutta on halukas palauttamaan esineen, mikäli saa naida jumalattaren (siksi siis valeasu). ${ }^{22}$ prymskviða vaikuttaa myyttisen diskurssin tuotokselta, jossa mytologinen juoni sovitettiin uuteen, Thor-jumalaa pilkkaavaan kertomukseen. Tämä esimerkki on kiinnostava myös, koska sovittamisen myötä kertomus muuntui uudessa, kristillisessä ympäristössä elinvoimaiseksi: lopulta se levisi kautta koko Skandinavian ja säilyi ainoana oletettavasti myyttisenä kertomuksena, jota on tallennettu skandinaavisesta balladitraditiosta (Liestøl 1970, 18).

Uskonnollisten muutosten yhteydessä yhteisöllisten näkökulmien ja positioiden määrittäminen myyttisen diskurssin avulla synnyttää moninaisia ja kiehtovia tuotoksia, kuten yllä käsitelty kertomus Jeesuksen taisteluun haastavasta Thorista

19 Tämä tavataan kirjoituksessa, joka on merkitty vuodelle 6579 (1071 j.a.a.); kristityn vakuutus siitä, että pakanajumala on itse asiassa Antikristus, tavataan myös vuodelle 6582 (1074 j.a.a.) tehdyssä merkinnässä.

20 Esim. Jómal (itämerensuomen sanasta jumala), jonka sanotaan muinaisislantilaisessa saagakirjallisuudessa olleen bjarmien jumala (ks. Frog 2014c, 466-467).

21 Esim. motiivit tarinoissa, jotka liittyvät saamelaisten šamanismiin (ks. Jauhiainen 1998, 167168, tyypit D1031-1040; af Klintberg 2010, 264-265, tyypit M151-160; Christiansen 1958, 54-56, tyyppi 3080).

22 Koko pohdinta artikkelissa Frog 2014b, 142-154. 
osoittaa. Harvat näistä tuotoksista vakiintuvat ja säilyvät murroskauden ylitse, mikäli lainkaan. Tuotosten katoaminen voidaan yhdistää murroskauden itsensä katoamiseen: kun kristinuskosta tuli hallitseva, kiinnostus kansanomaisten jumalten kuvien haastamiseen sekä tämän haastamisen relevanssi vähenivät. prymskviðan tyyppiset tapaukset ovat poikkeuksia. Tässä tapauksessa juonen pitkäikäisyys näyttää liittyvän siihen tosiseikkaan, että kertomus rotevan parrakkaan miehen pukeutumisesta seksikkääksi morsiameksi, jotta saisi takaisin fallisen vasaransa ja voisi piestä varkaan, oli viihdyttävä yhä, vaikka Thorin auktoriteetin kyseenalaistaminen ei enää ollut ajankohtaista. Näiden myyttisen diskurssin tuotosten tarkastelu korostaakin, että symbolisen matriisin osatekijöitä ei käytetä yhdenmukaisesti: niitä käytetään jaettuina symboleina eri näkökulmista ja eriasteisella (ja mahdollisesti historiassa vaihtelevalla) kompetenssilla, ja näiden symbolien avulla voidaan haastaa ja määrittää vakiintuneita identiteettejä ja käsityksiä, kuten yllä kerrotuissa esimerkeissä on nähty.

\section{SYMBOLISEN MATRIISIN JA PERINNELAJIEN KOHTAAMISPINNAT}

Yleensä ottaen matriisin symbolijärjestelmät tapaavat keskittyä tiettyjen sosiaalisten toimintojen ympärille, minkä vuoksi symbolit ja niihin liittyvät katsantokannat ovat kosketuksissa perinnelajien kanssa. Nykyaikaiset ajatukset suomalais-karjalaisesta mytologiasta ovat kehittyneet pääasiassa kalevalamittaisen epiikan ja loitsujen tutkimuksen pohjalta. Nämä perinnelajit liittyvät tiiviisti toisiinsa. Kalevalamittaisen runouden keskeisin toimija on Väinämöinen, demiurgi ja kulttuurin perustaja, jolla on keskeinen rooli nykyisen maailmanjärjestyksen perustamisessa. Hän on "tietäjä iän ikuinen" ja tarjoaa näin ollen identiteettimallin tietäjälle (ks. Honko 1998, 20-29); kertomukset hänestä kuvaavat tietäjän käyttämien loitsujen syntyä ja tarjoavat esikuvallisia malleja maagisille tapahtumille, joita itse loitsut kuvaavat. Väinämöisestä ei kuitenkaan kerrota proosamuodossa, häneen vedotaan harvoin suoraan loitsuissa ja häntä ei "palvota". (Frog 2013c, 75-83.) Sen sijaan tietäjä vetoaa ukkosenjumala Ukkoon (joka sulautuu kristilliseen Jumalaan) pääasiallisena voimansa lähteenä, ja Ukkoa "palvotaan", siis hänet liitetään rituaaleihin, tabuihin ja niin edelleen. Ukolla ei kuitenkaan ole minkäänlaista roolia maailman synnyssä tai maailmanjärjestyksen perustamisessa, eikä hänestä kerrota kalevalamittaisessa epiikassa aktiivisena toimijana, vaikka hän onkin vahvasti läsnä proosakerronnassa. (Frog 2013c, 72-75.) Vaikkei Ukko olekaan yhtään vähemmän merkityksellinen tietäjälle kuin Väinämöinen - joskin hän on sitä eri tavoin - Ukolla ei ole epiikassa aktiivista roolia Väinämöisen ja tämän kumppanien rinnalla. Nämä jumalat näyttäytyvät siis varsin eri tavoin eri perinnelajeissa, vaikka liittyvätkin samantyyppiseen spesialistiin ja jopa samoihin rituaalisiin käytänteisiin kuten parantamiseen.

Vaikka Ukko ja Väinämöinen esiintyvät eri perinnelajeissa eri tavoin, loitsujen, epiikan ja (uskomus)tarinoiden välillä ei näytä olevan mytologian suhteen jyrkkiä ristiriitoja. Kontrasti on suurempi, mikäli vertaamme edellä mainittuja lajeja karjalaiseen itkuvirsiperinteeseen, jota toiset spesialistit - ei tietäjät - ovat esittäneet muissa konteksteissa. ${ }^{23}$ Sekä Väinämöinen että Ukko loistavat 
Frog: Myyttinen diskurssi ja mytologian symbolinen matriisi

[http://www.elore.fi/arkisto/1_15/frog.pdf]

poissaolollaan itkuvirsissä - kuten myös Neitsyt Maria (Stepanova 2012, 276; $2014,215)$, joka oli muutoin keskeinen sekä muissa naisten traditioissa että loitsuissa (esim. Siikala 1992, 167-172; Timonen 1994). Itkuvirret on osoitettu tietyille edesmenneille yksilöille, kuolleiden esivanhempien yhteisölle sekä merkitykseltään hämärälle jumalallisten voimien kategorialle (syndyzet), joka voi olla sulautunut kristilliseen "pelastajaan" (spuassuzet). Itkuvirsien välittämä tuonpuoleisen topografia eroaa niin ikään muiden karjalaisten perinnelajien välittämästä kuvasta. Itkuvirsistä esimerkiksi puuttuu elävien ja kuolleiden maailmat erottava joki tai tuonpuoleiseen johtavaa polkua vahtiva koira, jotka ovat muutoin keskeisiä kuvia kalevalamittaisessa epiikassa ja loitsuissa. Itkuvirsissä mainitaan myös esimerkiksi vaskiportaat, mikä viittaa vertikaaliseen liikkeeseen maailmojen välillä pikemmin kuin horisontaaliseen liikkeeseen, mikä on puolestaan luonteenomaista epiikalle. ${ }^{24}$ Huolimatta siitä, että perinnelajit ovat esiintyneet samoissa yhteisöissä vuosisatojen ajan, ne näyttävät käyttävän symbolisesta matriisista varsin eri osia ja vain varsin rajoitettua jaettujen symbolien määrää. Kun otetaan huomioon, että yhtäältä itkuvirret ja toisaalta epiikka ja loitsut ovat sulauttaneet itseensä joukon kristillisiä symboleja, niiden voidaan kuvata edustavan mytologioita, jotka ovat yhtä erilaisia tai yhtä samanlaisia verrattuna toisiinsa kuin verrattuna kristinuskoon.

\section{Mytologian REKISTERIT}

Mytologian variaatiota perinnelajin mukaan voidaan lähestyä rekisterin käsitteen avulla. Tätä lähestymistapaa voidaan myös soveltaa sellaiseen mytologian variaatioon, joka tapahtuu uskonnonmukaisessa positioitumisessa, kuten kristillistymiseen liittyvässä myyttisessä diskurssissa. Siinä missä kieli käsitetään yleensä abstraktina ja yhdenmukaisena kokonaisuutena, rekisteri kehitettiin sosiaalilingvistiikassa kuvaamaan kielen variaatiota suhteessa tilanteeseen, kontekstiin ja osallistujien välisiin suhteisiin (erit. Halliday 1978; ks. myös Agha 2001; 2007). Kuva kielestä ideaalina, yhdenmukaisena ja homogeenisena järjestelmänä vaihtui tällöin paljon hienovaraisempaan kuvaan. Se, mitä kutsumme kieleksi, näyttäytyy joukkona potentiaalisia sanastoresursseja sekä kieliopin ja lausumisen viitekehyksiä, jotka muodostavat lukuisia kokonaisuuksia eli rekistereitä. Yksikään rekisteri ei kuitenkaan käsitä koko potentiaalista sanastoa, sanojen merkitykset eivät ole välttämättä samoja, eikä sanoilla ole välttämättä samoja konnotaatioita eri rekistereissä. Puhekommunikaatio ei rajoitu kieleen, ja termi rekisteri onkin laajentunut kattamaan kielen ohella ilmaistuja paralingvistisiä piirteitä ja semiotiikkaa laajemminkin. Rekisteriperustaiset lähestymistavat ovat tavallisia eritoten suomalaisessa folkloristiikassa silloin, kun viitataan ilmaisun kielellisiin ja paralingvistisiin resursseihin tietyn perinnelajin yhteydessä (Koski 2011, 322-324). Rekisteriä täydentävää termiä moodi (mode) käytettiin jo varhain kuvaamaan välitysjärjestelmää, jonka avulla tietyn rekisterin merkitsijöitä viestitään, ovatpa nämä sitten signaaleja, kuten lauluääniä, tai jokin muu merkkien järjestelmä kuten kirjoitetun tekstin aakkoset. ${ }^{25}$ Aivan kuten puherekisterit välittyvät jonkin ilmaisumoodin puitteissa, teksteissään aivan yksitulkintainen, hän ei määritellyt sitä yhtä tyhjentävästi kuin muita termejä (ks. Shore 2015). Termin moodi käytöstä, ks. Frog 2014e, 198-202. 
Frog: Myyttinen diskurssi ja mytologian symbolinen matriisi

mytologian symbolit välittyvät jonkin puherekisterin puitteissa. Näin ollen puherekisteriä voidaan pitää mytologian symbolien ilmaisumoodina.

Tällä tavoin nähtynä perinnelajin tai kulttuurisen käytänteen mukaisen mytologian variaation voi olettaa olevan yhdenmukaista lingvistisen rekisterin sanaston sekä sen semantiikan, kieliopin ja ääntämysten kanssa. Toisin sanoen tietyillä symboleilla, kuten esimerkiksi naurisjumala Äkräällä, on varsin kapea ja erikoistunut käyttökonteksti. Toisia symboleja, kuten Ukkoa tai Neitsyt Mariaa, taas käytetään paljon laajemmin, joskaan tämä ei tarkoita, että niiden merkitykset olisivat yhdenmukaisia kaikissa mytologian rekistereissä. Tämä tuo meidät jälkeen mytologian pitkän aikavälin pysyvyyden äärelle: tässä kontekstissa pitkäkestoisuuden voidaan nähdä liittyvän vastaavaan, tiettyjen perinnelajien ja kulttuuristen käytänteiden pysyvyyteen. Tällaisten käytänteiden suhde mytologian rekistereihin on historiallisesti rakentunutta ja sosiaalisesti punniskeltua ja neuvoteltua - käytänteet toimivat nykyisyydessä menneisyydestä kumpuavina. Tapaamme pitää itsestään selvänä, että Maria ja Jeesus eivät seikkaile yhdessä Väinämöisen ja Ilmarisen kanssa, koska näemme näiden henkilöhahmojen kuuluvan yhtäältä kristilliseen, toisaalta kansanomaiseen perinteeseen. Samat laulajat lauloivat kuitenkin molempiin traditioihin kuuluvia kalevalamittaisia runoja vuosisatojen ajan, ja Väinämöisellä, Marialla ja Ukolla voi olla kullakin relevantti paikka yhdessä ja samassa loitsussa. (Frog 2013c, 74.) Symbolien ilmenemisen, yhdistelyn tai yhdistämättä jättämisen tavat eivät liity "kristillisen" ja "pakanallisen" perinteen eroavaisuuksiin laulajien nykyhetkessä, vaan ne palautuvat symbolien käytön konventioiden pitkäaikaiseen pysyvyyteen mytologian eri rekistereissä.

Eri uskontoihin liittyvien myyttisten rekisterien tarkastelu on mielekkäämpää, kun suunnataan huomio ideaaleista ja yhdenmukaisista mytologioista kohti rekisteripohjaista mallia. Samalla tavoin kuin puhumme suomesta ja englannista erillisinä kielinä, voimme puhua kristillisistä vs. ei-kristillisistä tai "tieteellisistä" vs. "kansanomaisista" mytologioista. Kun suomen ja englannin kielet tuodaan samaan ympäristöön, molemmat kasvattavat käytettävissä olevia kielellisiä resursseja, ja kielet voivat toimia vaihtoehtoisina rekistereinä: kielen (tai koodin) vaihto voi määräytyä kontekstuaalisesti tai olla strateginen valinta. ${ }^{26}$ Tiettyjen resurssien voidaan nähdä olevan keskeisiltä osin kosketuksissa niihin perinnelajeihin ja kulttuurisiin käytänteisiin, joiden yhteydessä niitä käytetään, viestitään ja määritetään sosiaalisesti, olivatpa nämä resurssit sitten kielellisiä tai symbolisia. Matriisin symboleja sovitetaan rekisteristä toiseen näiden käyttöympäristöjen välisessä vuorovaikutuksessa aivan kuten sanoja lainataan kielestä toiseen, jolloin niiden merkitys tai käyttö voi samalla muuttua. Mytologiassa tämä prosessi voi merkitä eri rekistereihin liittyvien symbolien uudelleentulkintaa tai yhdistymistä vastaavalla tavalla kuin ODININ kuva sulautuu toisinaan PAHOLAISEEN kristillisessä diskurssissa tai kun viittaus Spuassuun ('pelastaja, Kristus') sulautuu karjalaisessa itkuvirressä yliluonnollisiin voimiin, joita rekisterillä on puhuteltu historiassa. Vastaava prosessi johti siihen, että muinaisislannin termi purs säilyi myyttisessä Edda-runoudessa ja viittasi kosmologisiin, myyttisen ajan jättiläisiin, loitsuissa nykymaailman sairaus-toimijoihin

26 Tähän ilmiöön on viitattu termillä languaging (suurin piirtein 'kielellä vaikuttaminen', missä paino on kielellä (suom. huom.)); ks. esim. Jørgensen et al. 2011. 
ja saagoissa yksinkertaisesti "hirviöihin" (Frog 2013a). Näissä kaikissa tapauksissa matriisin symboleja hyödynnetään käyttäjien ja kyseisten rekisterien käytön näkökulmista. Tämä positioituminen muodostaa kosketuspinnan yhtäältä perinnelajin tai kulttuurisen käytänteen, toisaalta mytologian välille. Samalla perinnelajin ja sen käytön konventiot määrittävät kosketuspinnan konservatiivisuuden ja sosiaalisen innovatiivisuuden rajat - toisin sanoen sen, missä määrin symbolit muuttuvat tai pysyvät samankaltaisina ja millä tavoin, mikä puolestaan vaikuttaa mytologian pitkäaikaiseen säilymiseen kyseisessä rekisterissä.

Pitkällä aikavälillä jokainen mytologian rekisteri voi kerrostua historiallisesti eri tavoin sekä kielen että symbolien suhteen. Nämä kerrostumat ovat sekä käytön että rekistereiden välisten kosketuspintojen ja suhteiden tulosta. Mytologian eri rekisterit voivat lisäksi perustua muodostumiseensa tietyistä näkökulmista tiettyinä aikakausina. Näin ollen rekisterissä tapahtunut kehitys voidaan nähdä suhteessa perustaan, joka sillä on ollut tietyissä positioissa jonkin aiemman aikakauden symbolisessa matriisissa. ${ }^{27}$ Kääntäen, rekisterin vanhentuneisuus voi johtaa siihen, että kokonaisia alueita symbolisesta matriisista jää käytöstä. Sellaiset mytologian osatekijät, joilla on suhteellisen kapea käyttöalue, kuten nauriinjumala Äkräällä, ovat tietenkin erityisen haavoittuvaisia tässä suhteessa. Sosiaalisesti ja kulttuurisesti keskeisen symbolisen matriisin rekisterin luhistumisella voi kuitenkin olla kauaskantoisia seurauksia. Esimerkiksi kalevalamittaisen mytologian runsaus liittyy sen käyttöön rituaaleissa ja tietäjien maagisiin tarkoituksiin aina rautakaudelta alkaen, mutta kun nämä käyttötarkoitukset vanhentuivat modernisaation myötä, koko niihin liittyvä kuvitteellinen maailma alkoi unohtua. Tietyssä mielessä tämä kuvitteellinen maailma on pelastettu katoamiselta, vaikka se onkin vain vajavaisesti tarkasteltavissa, kuin särkyneessä kuvastimessa, tuhansissa arkistosirpaleissa. Tutkijan on muistettava, että näkökulmamme kyseisiin symboleihin nyky-yhteiskunnan matriisissa ovat perustavanlaatuisesti erilaiset kuin Arhippa Perttusen tai Simana Sissosen tapaisten laulajien muutama vuosisata sitten.

\section{TEORIA JA SEN HYÖDYNTÄMINEN KÄYTÄNNÖSSÄ}

Tämän katsauksen tavoitteena on ollut esitellä symbolisen matriisin käsitettä lähestymistapana mytologiaan ja sen tutkimukseen. Lähestymistavan avulla voidaan analysoida mytologian variaatiota ja moninaisuutta sen kulttuurisessa ympäristössä. Lähestymistavan perustana on käsitys mytologiasta symbolien järjestelmänä, jonka osatekijöitä käytetään ja jopa haastetaan myyttisessä diskurssissa. Mytologian tarkasteleminen sen sosiaalisessa ympäristössä symbolisen matriisin puitteissa mahdollistaa sekä mytologian käsittelemisen kokonaisuutena - vaikkei tämä kokonaisuus olisi sisäisesti järjestäytynyt per se - että siihen liittyvien näkökulmien ja sen käyttötapojen erittelyn ja näiden suhteuttamisen toisiinsa. Lähestymistapa soveltuu erityisen hyvin mytologian analysoimiseen tilannekohtaisissa käytänteissä. Matriisi tarjoaa entistä hienostuneemman välineen variaation rakenteellisen tason tutkimukseen, koska metodologiassa painotetaan matriisin osatekijöiden (kuvien, motiivien, teemojen, kertomusjaksojen, juonen) selväpiirteisen ja systemaattisen erittelyn roolia. Mytologian tilannekohtaisen, sosiaalisen käytön 
painottaminen korostaa, että matriisin osatekijät sekä niihin liittyvät näkökulmat ovat rakentuneet suhteessa sosiaalisiin käytänteisiin tai perinnelajeihin, jotka nekin ovat historiallisesti strukturoituneita.

Kieli- ja kielitiede-analogian avulla ilmaistuna symbolisen matriisin malli täydentää paikallisen ja alueellisen variaation tutkimista "murteina" lähestymällä variaatiota tietyssä ympäristössä "rekistereinä". Vaikka tutkimuksessa rekisterit abstrahoidaan semioottisiksi resursseiksi ja näin erotetaan ihmisistä, jotka niitä käyttävät, on äärimmäisen tärkeää ymmärtää rekistereiden ja niiden käyttöyhteyden välinen liitos. Rekisterit liittyvät monissa tapauksissa sosiaalisiin rooleihin tai jopa instituutioihin. ${ }^{28}$ Näitä rooleja ja niitä täyttäviä yksilöitä olen kuvannut matriisissa "positioitumiseksi". Positioituminen vaikuttaa osaltaan perinnelajien historialliseen muotoutumiseen sekä niiden myyttisten symbolien kerrostumiseen, joiden kanssa perinnelajit ovat kosketuksissa. Tässä esitetty malli tarjoaa viitekehyksen, jonka puitteissa on mahdollista yhtäältä käsitellä yhdenmukaisuuksia ja jännitteitä yksittäisten valintojen tai innovaatioiden sekä perinnelajien sosiaalisten konventioiden välillä, ja toisaalta kilpailevaa eri symbolien ja positioiden arvottamista matriisin sisällä laajemmalla sosiaalisella tasolla. Näiden pohdintojen ohella olen pyrkinyt korostamaan joustavien joskin hallitsevien symbolisen matriisin symbolien ja rakenteiden, siis resurssien, historiallista jatkuvuutta. Myyttisen diskurssin artikuloitumat, minä hyvänsä hetkenä historiassa, ovat osa prosessia, jossa perinteen menneisyys liitetään sen tulevaisuuteen tai vaihtoehtoisesti menneisyyden ja tulevaisuuden liitos katkaistaan.

Tässä hahmoteltu malli ei ole tarkoitettu välineeksi kaikkiin mytologiaan liittyviin tutkimuskysymyksiin. Se on tarkoitettu ennen muuta tutkimuksiin, jotka käsittelevät mytologiaa kulttuurisissa käytänteissä ja eritoten tutkimuksiin, joiden kohteena tai ongelmana on mytologian variaatio. Koska malli painottaa variaatiota, se myös problematisoi näkemykset, joissa mytologia nähdään enemmän tai vähemmän yhdenmukaisena kokonaisuutena, kuten tavallisesti on tehty eri kieliryhmiin liitettyjen mytologioiden suhteen - esimerkiksi suomalais-karjalaisen, skandinaavisen, uralilaisen tai indoeurooppalaisen mytologian. Tämä ei kuitenkaan tarkoita, että kyseiset kategoriat olisivat epävalideja niin kuin kielen rekistereiden käsittelykään ei johda siihen, että kieliä ei voisi käsitellä laajempina järjestelminä. Sen sijaan että pitäisin kategorioita toisensa poisulkevina, olen esittänyt vaihtoehtoisia ja täydentäviä tapoja tarkastella aineistoa sekä välineitä tiettyihin kysymyksiin vastaavalle tutkijalle. Kun eri malleja tarkastellaan yhdessä ja suhteessa toisiinsa, käy selväksi, että niiden variaatio on myös otetava huomioon. Mytologiat kun tuskin ovat niin yhdenmukaisia ja systemaattisia kuin pitkään on ollut tapana olettaa.

28 Eila Stepanova (2014) on hiljattain korostanut tätä luonnehtiessaan itkuvirsirekisteriä itkijöiden rekisteriksi pikemmin kuin kansanperinteen lajin rekisteriksi an sich. 
Frog: Myyttinen diskurssi ja mytologian symbolinen matriisi

Kirjallisuus

Aðalsteinsson, Jón Hnefill 1978: Under the Cloak. A Pagan Ritual Turning Point in the Conversion of Iceland. Uppsala: Acta Universitatis Upsaliensis.

Agha, Asif 2001: Registers of Language - Duranti, Alessandro (ed.), A Companion to Linguistic Anthropology. Malden: Blackwell. 23-45.

- 2007: Language and Social Relations. Cambridge: Cambridge University Press.

Arend, Walter 1933: Die typischen Scenen bei Homer. Berlin: Weidmannsche Buchhandlung.

Barner-Barry, Carol \& Hody, Cynthia 1994: Soviet Marxism-Leninism as Mythology - Political Psychology 15(4): 609-630.

Barthes, Roland 1972: Mythologies. New York: Hill \& Wang. [1957]

Briggs, Charles L. \& Bauman, Richard 1992: Genre, Intertextuality, and Social Power - Journal of Linguistic Anthropology 2(2): 131-172.

Cassirer, Ernst 1925: Sprache und Mythos. Ein Beitrag zum Problem der Götternamen. Leipzig: B.G. Teubner.

Christiansen, Reidar Th. 1958: The Migratory Legends. A Proposed List of Types with a Systematic Catalogue of the Norwegian Variants. Helsinki: Academia Scientiarum Fennica.

Cleasby, Richard \& Vigfússon, Gudbrand 1896: An Icelandic English Dictionary Chiefly Founded on the Collections made from Prose Works of the 12th-14th Centuries. Oxford: Clarendon Press.

Cross, Samuel Hazzard \& Sherbowitz-Wetzor, Olgerd P. (eds. \& trans.) 1953: The Russian Primary Chronicle. Laurentian Text [online]. Cambridge: Mediaeval Academy of America. <http://hudce7.harvard.edu/ ostrowski/pvl/ index.html> [4.5.2015]

Csapo, Eric 2004: Theories of Mythology. London: Blackwell.

Doty, William G. 2000: Mythography. The Study of Myths and Rituals. Tuscaloosa: University of Alabama Press. [1986]

Eliade, Mircea 1968: Myth and Reality. Harper Torchbooks. New York: Harper \& Row. [1963]

Frog 2010: Baldr and Lemminkäinen. Approaching the Evolution of Mythological Narrative through the Activating Power of Expression. A Case Study in Germanic and Finno-Karelian Cultural Contact and Exchange. UCL Eprints. London: University College London.

- 2011: Circum-Baltic Mythology? The Strange Case of the Theft of the ThunderInstrument (ATU 1148b) - Archaeologia Baltica 15: 78-98.

- 2013a: The (De)Construction of Mythic Ethnography I. Is Every purs in Verse a purs? - RMN Newsletter 6: 52-72.

- 2013b: The Parallax Approach. Situating Traditions in Long-Term Perspective Frog \& Latvala, Pauliina with Leslie, Helen F. (eds.), Approaching Methodology. Helsinki: Academia Scientiarum Fennica. 101-131.

- 2013c: Shamans, Christians, and Things in between. From Finnic-Germanic Contacts to the Conversion of Karelia - Słupecki, Leszek \& Simek, Rudolf (eds.), Conversions. Looking for Ideological Change in the Early Middle Ages. Vienna: Fassbaender. 53-98. 
- 2014a: From Mythology to Identity and Imaginal Experience. An Exploratory Approach to the Symbolic Matrix in Viking Age Åland - Ahola, Joonas, Frog \& Lucenius, Jenni (eds.), The Viking Age in Aland. Insights into Identity and Remnants of Culture. Helsinki: Academia Scientiarum Fennica. 349-414.

- 2014b: Germanic Traditions of the Theft of the Thunder-Instrument (ATU 1148b). An Approach to Prymskviða and Pórr's Adventure with Geirrøðr in CircumBaltic Perspective - Heide, Eldar \& Bek-Petersen, Karen (eds.), New Focus on Retrospective Methods. Resuming Methodological Discussions. Case Studies from Northern Europe. Helsinki: Academia Scientiarum Fennica. 120-162.

- 2014c: Myth, Mythological Thinking and the Viking Age in Finland - Ahola, Joonas \& Frog with Tolley, Clive (eds.), Fibula, Fabula, Fact - The Viking Age in Finland. Helsinki: SKS. 437-482.

- 2014d: Mytologia on katsojan silmässä. Miten myytit merkityksellistävät maailmaa - Knuuttila, Seppo \& Piela, Ulla (toim.), Ympäristömytologia. Kalevalaseuran vuosikirja 93. Helsinki: SKS. 59-73.

- 2014e: Parallelism, Mode, Medium and Orders of Representation - Frog (ed.), Parallelism in Verbal Art and Performance. Pre-Print Papers of the SeminarWorkshop, 26th-27th May 2014. Helsinki: Folklore Studies, University of Helsinki. 185-207.

Frye, Donald K. 1968: Old English Formulaic Themes and Type-Scenes Neophilologus 52(1): 48-54.

Goodman, Lenn E. 1993: Mythic Discourse - Biderman, Shlomo \& Scharfstein, Ben-Ami (eds.), Myths and Fictions. Leiden: Brill. 51-112.

Gunnell, Terry 2009: Ansgar's Conversion of Iceland - Scripta Islandica 60: 105-118.

Halliday, M. A. K. 1978: Language as Social Semiotic. London: Edward Arnold.

Honko, Lauri 1998: Textualizing the Siri Epic. Helsinki: Academia Scientiarum Fennica.

Hoppál, Mihály 2010: Uralic Mythologies and Shamans. Budapest: Hungarian Academy of Sciences.

Jauhiainen, Marjatta 1998: The Type and Motif Index of Finnish Belief Legends and Memorates. Helsinki: Academia Scientiarum Fennica.

Jørgensen, J. N., Karrebæk, M. S., Madsen, L. M. \& Møller, J. S. 2011: Polylanguaging and Superdiversity - Diversities 13(2): 23-37.

Kamppinen, Matti 1989: Cognitive Systems and Cultural Models of Illness. A Study of Two Mestizo Peasant Communities of the Peruvian Amazon. Helsinki; Academia Scientiarum Fennica.

Kaplan, Merrill 2011: Thou Fearful Guest. Addressing the Past in Four Tales in Flateyjarbók. Helsinki: Academia Scientiarum Fennica.

af Klintberg, Bengt 2010: The Types of the Swedish Folk Legend. Helsinki: Academia Scientiarum Fennica.

Koski, Kaarina 2011: Kuoleman voimat. Kirkonväki suomalaisessa uskomusperinteessä. Helsinki: SKS.

Kuusi, Matti 1963: Keskiajan kalevalainen runous - Kuusi, Matti (toim.), Suomen Kirjallisuus I. Helsinki: SKS. 273-397.

Lakoff, George 1987: Women, Fire, and Dangerous Things. What Categories Reveal about the Mind. Chicago: Chicago University Press. 
Lassen, Annette 2011: Oden på kristent pergament. København: Museum Tusculanums Forlag.

Lévi-Strauss, Claude 1962: Le totemisme aujourd'hui. Paris: PUF.

- 1967: Structural Anthropology. Anchor Book. Doubleday: Garden City. [1958]

Liestøl, Knut 1970: Den norrøne arven. Oslo: Universitetsforlaget.

Loorits, Oskar 1932: Das Märchen vom gestohlenen Donner-instrument bei den Esten. Tartu: Gelehrte estnische Gesellschaft.

Lord, Albert B. 1960: The Singer of Tales. Cambridge: Harvard University Press.

Lotman, Iu. M. \& Uspenskii, B. A. 1976: Myth - Name - Culture - Henryk Baran (ed.), Semiotics and Structuralism. Readings from the Soviet Union. White Planes: International Arts and Sciences Press. 3-32.

Lyle, Emily 2012: Ten Gods. A New Approach to Defining the Mythological Structures of the Indo-Europeans. Newcastle upon Tyne: Cambridge Scholars Publishing

Malinowski, Bronislaw 1948: Myth in Primitive Psychology - Malinowski, Bronislaw, Magic, Science and Religion. Garden City: Doubleday Anchor. 93-148. [1926]

Meletinskij, Eleazar Moiseevich 1997: Das paläoasiatische mythologische Epos. Der Zyklus des Raben. Berlin: Reinhold Schletzer.

Miller, William Ian 1991: Of Outlaws, Christians, Horsemeat, and Writing. Uniform Laws and Saga Iceland - Michigan Law Review 89(8): 2081-2095.

Napolskikh, Vladimir 1992: Proto-Uralic World Picture. A Reconstruction Pentikäinen, Juha (ed.), Shamanism and Northern Ecology. Berlin: Mouton de Gruyter. 3-20.

- 2012: The Earth-Diver Myth (A812) in Northern Eurasia and North America. Twenty Years Later - Frog, Siikala, Anna-Leena \& Stepanova, Eila (eds.), Mythic Discourses. Studies in Uralic Traditions. Helsinki: SKS. 120-140.

Sveinsson, Einar ól. (út.) 1952: Brennu-Njáls saga. Reykjavík: Hið Íslenzka fornritafélag.

Propp, V. 1968: Morphology of the Folktale. Austin: University of Texas Press. [1928]

Rowland, Robert C. 1990: On Mythic Criticism - Communication Studies 41(2): 101-116.

Ostrowski, Donald (ed.) 2003: The Povest' vremennykh let. An Interlinear Collation and Paradosis I-III. Cambridge: Harvard Ukrainian Research Institute.

Sanmark, Alexandra 2004: Power and Conversion. A Comparative Study of Christianization in Scandinavia. Uppsala: Department of Archaeology and Ancient History, Uppsala University.

Shore, Susanna 2015 (forthcoming): Register in Systemic-Functional Linguistics - Agha, Asif \& Frog (eds.), Registers of Communication. Helsinki: SKS.

Siikala, Anna-Leena 1992: Suomalainen šamanismi. Mielikuvien historiaa. Helsinki: SKS.

- 2012: Itämerensuomalisten mytologia. Helsinki: SKS.

Stepanova, Eila 2012: Mythic Elements of Karelian Laments. The Case of syndyzet and spuassuzet - Frog, Siikala, Anna-Leena \& Stepanova, Eila (eds.), Mythic Discourses. Studies in Uralic Traditions. Helsinki: SKS. 257-287. 
- 2014: Seesjärveläisten itkijöiden rekisterit. Tutkimus äänellä itkemisen käytänteistä, teemoista ja käsitteistä. Joensuu: Suomen Kansantietouden Tutkijain Seura.

Thompson, Stith 1955: Narrative Motif-Analysis as a Folklore Method. Helsinki: Academia Scientiarum Fennica.

- 1955-1958: Motif-Index of Folk-Literature I-VI. Helsinki: Academia Scientiarum Fennica.

Timonen, Senni 1994: The Mary of Women's Epic - Siikala, Anna-Leena \& Vakimo, Sinikka (eds.), Songs Beyond the Kalevala. Transformations of Oral Poetry. Helsinki: SKS.

Uther, Hans-Jörg 1997-1999: Donner - Ranke, Kurt et al. (Hg.), Enzyklopädie des Märchens. Handwörterbuch zur historischen und vergleichenden Erzählforschung III. Berlin: de Gruyter. 762-766.

- 2004: The Types of International Folktales I-III. Helsinki: Academia Scientiarum Fennica.

Valk, Ülo 2012: Thunder and Lightning in Estonian Folklore in the Light of Vernacular Theories - Frog, Siikala, Anna-Leena \& Stepanova, Eila (eds.), Mythic Discourses. Studies in Uralic Traditions. Helsinki: SKS. 40-67.

West, M. L. 2007: Indo-European Poetry and Myth. Oxford: Oxford University Press.

Witzel, E. J. Michael 2012: The Origins of the World's Mythologies. Oxford: Oxford University Press.

Dosentti Frog on folkloristiikan tutkijatohtori Helsingin yliopistossa. Katsauksen on kääntänyt FT Joonas Ahola. 